\title{
POLICY RECOMMENDATIONS FROM EMPLOYERS FOR ENHANCING SKILLS THROUGH ODL
}

\author{
Dr. Anshu MIGLANI \\ Inter University Consortium \\ Indira Gandhi National Open University (IGNOU) \\ New Delhi, India \\ Ashish K. AWADHIYA \\ Inter University Consortium \\ Indira Gandhi National Open University (IGNOU) \\ New Delhi, India \\ Dr. Nisha SINGH \\ Inter University Consortium \\ Indira Gandhi National Open University (IGNOU) \\ New Delhi, India \\ Dr. K. GOWTHAMAN \\ Inter University Consortium \\ Indira Gandhi National Open University (IGNOU) \\ New Delhi, India \\ Dr. Gayatri KANSAL \\ School of Engineering and Technology \\ Indira Gandhi National Open University (IGNOU) \\ New Delhi, India
}

\section{ABSTRACT}

This paper aims at seeking recommendations for the Open and Distance Learning (ODL) policy from the industry to ensure learners graduating from ODL system are employable and are at par with those who have graduated from conventional system. Survey from total 97 employers spread over $\mathbf{7}$ industry sectors indicated that policy intervention is required to enhance skill development through ODL. This will enable ODL system and its learners to overcome major challenges related to credibility and recognition. These recommendations stressed on enhancing the quality of ODL education and skill development through collaboration between academia and industry and use of technology.

It is highly advocated that government agencies should ensure that quality parameters like recognition, accreditation, industry relevant curricula, be implemented and fulfilled by ODL institutions as well. Apart from the core subject knowledge, employers also stressed upon the need to foster employability skills such as problem solving, critical thinking etc. in the curriculum. Both the quality of ODL programmes and its linking with skill development will enable ODL system to bridge the gap between demand and supply of skilled manpower.

The herculean task of skilling millions of people in India can be achieved through collaboration and use of technology. Collaboration is the key factor to bring about synergy between academia and industry. It will enable the learners' job ready and give productive output at their work places, there by contributing to the economic development of the country. Alliance will also provide learners a smooth transition from learning to earning.

Keywords: ODL, skill development, industry, employment, policy. 


\section{INTRODUCTION}

India is a country with significant knowledge economy and availability of human resource at all the levels. However, India still lacks skilled human resource despite having huge work force (Mohapatra and Mahapatra, 2016). It is therefore important that policy makers must focus on imparting the relevant and quality skills as they provide better employment opportunities (Aggarwal, 2016). It will improve the capability of the present system and will enable to meet the demand supply gap in the emerging globalized economy.

In recent years the Indian policy makers are aiming towards making India as a biggest skilled human resource supplier to the global economy (FICCI, 2015). National Policy on Skill Development was formulated to address different challenges in skill development. The government has also listed skill development as one of its priorities which aims to enhance participation of youth, seek greater inclusion of women, disabled and other disadvantaged sections into the workforce.

The National Skill Development Mission, titled as 'Skill India', under the Ministry of Skill Development and Entrepreneurship (MSDE) is supported by three other institutions: National Skill Development Agency (NSDA), National Skill Development Corporation (NSDC), and Directorate General of Training (DGT). The Mission has been developed to create convergence across sectors and States in terms of skill training activities. Seven submissions have been proposed initially to act as building blocks for achieving overall objectives of the Mission. They are: (i) Institutional Training, (ii) Infrastructure, (iii) Convergence, (iv) Trainers, (v) Overseas Employment, (vi) Sustainable Livelihoods, (vii) Leveraging Public Infrastructure. (http://www.skilldevelopment.gov.in/ national skillmission.html)

Skill Development in India has its own set of challenges. Since, skill development in India does not show the inherent linking with academia and industry, there is a gap between skills required by the industry and those imparted through the educational and training institute due to lack of collaboration and interaction. Moreover, vocational institutes in India focus mainly to impart technical skills only. This leads to unemployable graduates. Dissatisfied with the current educational deliverable, many companies have made their own Training, Research and Development centers through which they develop human resource. Though the Skill Development also focuses on the Public Private Partnership (PPP) Model there is lack of synergy among Indian formal education system, skill development environment and industry requirement (Sharma and Nagendra, 2016).

With changing global economic environment, there is intense need to incorporate dynamic changes in the skill development system of India. This may be done by making skill development an integral part of the educational curriculum and life long learning. This can be achieved most effectively only by the active involvement of the industry in the curriculum development and apprenticeship training.

Moreover, formal education system has the limited capacity to bridge the demand supply gap in skill development for large population of India due to inadequate infrastructure constraint in comparison to huge demand of labour. The problem of insufficient infrastructure is same in big cities as well as small towns and villages. There aren't many trained and highly skilled trainers available either, which further make skill development a big challenge.

In such scenario, Open and Distance learning (ODL) has the potential to impart training and skill development in India as it has the capability to reach to the masses. ODL can contribute towards Technical and Vocational Education and Training (TVET) to the large section of the society especially those, who in the normal course is beyond the umbrella of higher education. Skill development through ODL is also the need of time due to requirement of on-job learning to keep pace with changing technologies. Therefore, there 
is a need for collaboration with industry/ employer to establish a robust system for skill development through ODL.

There have been several case studies in which collaboration with industry especially technical courses have yielded significant results. Indira Gandhi National Open University (IGNOU), the largest Open University in the world launched Bachelors of Science (B.Sc.) degree programme in collaboration with Director General of Shipping (DGS) in 2004 in order to develop human resource for the career in Merchant Navy. Total 3147 learners were enrolled in this programme between 2007-10 (IGNOU, 2017). The employability of the learners after the course completion was found to be hundred percent.

On similar lines, the Advanced Certificate in Power Distribution Management (ACPDM) programme was developed by IGNOU in collaboration with the Ministry of Power for professionals employed in electrical power utilities or electricity sector to upgrade their skills. More than $\mathbf{3 5 0 0}$ learners were trained under this programme between 2006-2015 (IGNOU, 2017).

Such experiments of collaborative initiative clearly demonstrate the viable model for skill development which not only assures employability to learners but also a rewarding manpower to the industry. However, TVET through ODL is going through its own challenges like credibility and recognition issues due to various reasons (Mishra \& Bartram, 2002). In case of India education, skill development and employment are no where whether it is imparted through ODL mode or conventional Face to Face mode. In such a scenario, a policy intervention is needed to build the collaboration between institutions (be it ODL or conventional system) providing skill development and employer. This could be only possible if a national qualification framework be developed which comprises of the stakeholders from the academia, employers and skill development. Such a framework will ensure parity and recognition among the two education system. This paper aims to seek recommendations in the ODL policy from the industry to ensure learners graduating from ODL system are employable and are at par with those who have graduated from conventional system.

\section{METHOD}

The purpose of this study was to seek recommendations in the ODL policy from the industry to ensure learners graduating from ODL system are employable and are at par with those who have graduated from conventional system. This study was survey research under quantitative research method which falls under category of descriptive research. The deliberate of the descriptive research studies are to acquire information related to present status of a given event. The descriptive research is to explore "what exists" with respect to variables or conditions in a situation. While conducting descriptive research there is a need to identify the type of data obtained and exact nature of its population (IGNOU, 2001).

The survey was developed to collect inputs from employers. It was reviewed for content validity by experts in the domain of ODL. After incorporating the comments and suggestions from the reviewers the questionnaire was tested for its reliability through test-retest method. The final questionnaire consisted of five items to evaluate the recommendations given by the employers. The survey questionnaire was administered online to collect the data.

\section{RESULT AND DISCUSSION}

Ninety-seven (97) employers in total responded to the survey. The data was analyzed under the following two main heads:

$>$ Employers' profile and

$>$ Recommendations from the employers. 


\section{Employers' Profile}

Employers' profile was analysed based on their business domain and the employee size of the business/ organisation/ company.

\section{Business Domain}

The business domain of the employers who responded is given in Table 1.

Table 1. Business Domain of the Employers

\begin{tabular}{|c|c|c|c|}
\hline S. No. & Business Domain & No. of responses & Response \% \\
\hline 1 & Education, Training and R\&D & 33 & 34.02 \\
\hline 2 & Information Technology & 14 & 14.43 \\
\hline 3 & Defense & 8 & 8.25 \\
\hline 4 & Manufacturing & 7 & 7.22 \\
\hline 5 & Services & 4 & 4.12 \\
\hline 6 & Engineering & 2 & 2.06 \\
\hline 7 & Government & 2 & 2.06 \\
\hline 8 & Others & 10 & 10.31 \\
\hline \multirow[t]{2}{*}{9} & Unanswered & 17 & 17.53 \\
\hline & Total & 97 & 100 \\
\hline
\end{tabular}

According to the survey, as presented in Table 1, 34\% of employers belong to academic domain such as Education, Training and Research and Development. 14\% of employers were from Information Technology domain. 34\% employers belong to various sectors comprised of Defense, Manufacturing, Services, Engineering and Government. While 18\% employers did not respond to it.

Size of the Business/Organisation/Companies

The size of various organisation/ companies from which employees responded could be estimated from the number of employees which is provided in Table 2 . According to the table, 34\% of the employers had small size of business with less than equal to 25 employees. While, $26 \%$ of employers had large business size with more than one thousand employees on the roll. Remaining $40 \%$ had medium size business whose employees varied between 26 to 1000 in numbers.

Table 2. Number of Employees on roll

\begin{tabular}{|c|c|c|c|}
\hline S. No. & No. of Employees & No. of responses & Response \% \\
\hline 1 & $<=25$ & 33 & 34.02 \\
\hline 2 & 26-100 & 20 & 20.62 \\
\hline 3 & $101-1000$ & 19 & 19.59 \\
\hline \multirow[t]{2}{*}{4} & $>1000$ & 25 & 25.77 \\
\hline & Total & 97 & 100.00 \\
\hline
\end{tabular}


Recommendations from Employers

Recommendations from Employers were received in the areas of Skill Development and its driving forces, areas for collaboration and overall improvement of quality of ODL.

\section{Skill Development}

Employers strongly seek academic credentials and subject knowledge for all type work profile. It is also important for employers that employee should be equipped with professional skills such as oral and written communication, collaboration and teamwork, and critical thinking and problem-solving, along with innovative and entrepreneurial thinking and the ability to contribute to multidisciplinary teams which are very critical to work in the corporate sector (Council of Graduate Schools and Educational Testing Service, 2012).

According to the survey, most important recommendation of the employers was to stress upon the Skill Development reforms. Life skills required in employable graduates by employers are given in Table $3.86 .75 \%$ of employers were of the opinion that it is important for ODL graduates to be competent in life skills like communication, critical thinking skills, problem solving skills and many more.

All these skills are termed as soft or professional skills. In this competitive job market, recruitment criteria do not end at qualification or technical level. Presence of soft skills in the prospective employee gives an edge of others candidates. Recruiters are also interested in people who have the personality that reflect leadership, team work spirit, good communication etc. Soft skills are also important while dealing with clients as well as interacting with colleagues. Soft skills are valued as they enable people to work in teams while maintaining a productive and healthy work environment in organisations as a whole (Robles, 2012).

By developing these skills, their prospects of getting employment and further rise in the career path may be augmented in their respective job domains. Communication skill $(95.88 \%)$ was ranked as the most important skills which is required among job seekers. Apart from communication, other important skills were creative thinking $(92.78 \%)$, problem solving $(\mathbf{9 2 . 7 8 \% )}$ ) and planning skills $(91.75 \%)$.

Literature suggests that ODL has the inherent potential to inculcate communication skills (like listening, reading, writing and oral skills), intellectual skills (reasoning abilities) and specialized skills (scientific and technological abilities as well as management skills). The distance learning institutions does not offer classroom-based instructions as in conventional education system. Distance learning involves geographic separation of teachers and students., however, there is constant academic interaction through the use of various technologies to facilitate student-teacher and student-student communication. These days however, various means of electronic communications, such as e-mail, mobile phones are used, over traditional forms of communication, such as the postal system. This leads learners to keep working up their reading, listening as well as writing skills in order to communicate effectively. Learners also need to go through their study material mateirals independently apart from their responsibilities at home or at office which makes good at multi-tasking and managing their commitments. There is no better way to impart management skills than the real life challanges and targets in front of learners. The requirements of these skills for the job seekers have also been highlighted by Gauvreau et al., 2016. Besides imparting the skills ODL also empowers its learners with decision making, taking responsibilities and ability to make informed choices (IGNOU, 2013). It was further demonstrated that these skills can effectively be imparted through technological intervention. Therefore, we can say that ODL can develop these skills as effectively as any formal system. 
Table 3. Skills required for employability

\begin{tabular}{|c|c|c|c|}
\hline S. No. & Responses & No. of responses & Response \% \\
\hline 1 & Communication skills & 93 & 95.88 \\
\hline 2 & Problem solving skills & 90 & 92.78 \\
\hline 3 & Creative thinking & 90 & 92.78 \\
\hline 4 & Planning skills & 89 & 91.75 \\
\hline 5 & Teamwork & 87 & 89.69 \\
\hline 6 & Decision making skills & 84 & 86.60 \\
\hline 7 & Multitasking & 83 & 85.57 \\
\hline 8 & IT Skills & 81 & 83.51 \\
\hline 9 & Ability to apply knowledge to real world settings & 81 & 83.51 \\
\hline 10 & Leadership skills & 80 & 82.47 \\
\hline 11 & Analytical thinking Skills & 80 & 82.47 \\
\hline 12 & Global perspective & 80 & 82.47 \\
\hline 13 & Critical thinking Skills & 76 & 78.35 \\
\hline
\end{tabular}

* Respondents may select more than one option, so percentages may add up to more than 100\%.

\section{Driving Forces for Skill Development}

Having discussed about skill development to improve employability among ODL graduates, it is also important to learn and understand its driving forces from the perspective of employers. According to the survey, employers feel that the key to effective skill development among learners is the collaboration. As per Table 4, 93.8\% employers have the opinion that collaboration between industry and academia is the key factor to bring about synergy between academia and industry. Academia need to understand the skill set which is required in the coming time. It is very important for the academia to develop a course curriculum which is relevant to the changing industry need or else it can create gap resulting in unemployable youth. Collaboration also enhances the quality of education which can be gauged through the employability quotient of the institute. Industry led training will make the learners' job-ready and give productive output at their work places, thereby reducing the cost of training after recruitment. It will therefore contribute to the economic development of the country. Alliance will also provide learners a smooth transition from learning to earning. Thus pro-active involvement of industry with academia is a profitable proposition for both stakeholders. Various areas in which collaboration can take place has been listed in Table 5.

Apart from collaboration, another important force which leads to skill development is the use of technology. Technology has been credited by $75.3 \%$ of employers for bringing momentum which can skill millions of people in the country. As technology is advancing, its costs are dropping. It has become cheaper and thus more affordable to low-level income group. This has increased its penetration in the society. According to the study conducted 
by Author, 2014, ICT infrastructure is not a constraint at learner level as most of them are equipped with one or more ICT based devices.

Social networking using technology has redefined collaboration like never before. Social media such as blogs, wikis, Skype or Google Hangout, Facebook; WhatsApp have become a global platform for learners discuss, learn and enrich their learning experience through shared interaction. Interactivity of these media has made tremendous contribution in bridging the gap between teachers and learners (Mnkandla and Minnaar, 2017). Hence, there is a need to generate ICT based tutorials complemented with social networking tools for learning and teaching process in order to achieve skill development goals.

Mobile learning (m-learning) is further revolutionizing the education by providing 'Just in time' learning that will provide ready access to knowledge. m-learning has the potential to engage the learner to a greater extent. It enhances the collaboration and didactic conversation, thereby reducing the feeling of isolation for learners in an ODL system (Author, 2017). However, $\mathrm{m}$-learning is still at its nascent phase and hence facing several challenges like lack of support for instructional design for m-learning; lack of institutional policy for $\mathbf{m}$-learning, lack of infrastructure/technological support. It is therefore important for institutions to adopt policy to implement m-learning in order to provide a guiding framework to develop implement it successfully (Author, 2016).

Another education technology, Massive Open Online Courses (MOOCs) has opened educational avenues by providing learning experience to those who cannot afford to attend universities, resulting in large number of enrolments across the globe. With the development of MOOCs, it has becoming much easier, affordable and flexible way to provide access to the quality learning resources cutting across geographical barriers (Gamage, et al., 2016).

The project, 'Study Webs of Active Learning for Young Aspiring Minds' (SWAYAM) has been initiated by Ministry of Human Resource Development (MHRD), Government of India. SWAYAM aims at bridging 'Digital Divide' providing an integrated portal for online courses, from High School till all higher education and skill sector courses to ensure that students get access to quality learning material through ICT and opportunities for a life-long learning. (https://swayam.gov.in/About)

However, the success of MOOCs is still questionable. Despite large number of enrollments, MOOCs is facing immense dropouts during the course delivery.

Table 4. Driving Forces for Skill Development

\begin{tabular}{clcc}
\hline S. No. & Responses & No. of responses & Response \% \\
\hline 1 & Collaboration between industry and academia & 91 & $93.8 \%$ \\
2 & Use of technology & 73 & $75.3 \%$ \\
\hline
\end{tabular}

\section{Areas for Collaboration}

Employers have recommended various areas where collaboration can be carried out between industry and academia. These areas are listed in Table 5. According to the table, the most important area of collaboration is to provide employment to the learners after the completion of the course $(\mathbf{7 7 \%})$, followed by collaboration while initiating a new programme as per industry needs $(\mathbf{7 4 . 3 \%})$ and hands-on experience and training $(\mathbf{7 4 . 3 \%})$.

While, it is important for employers to seek fresh graduates, it is extremely important that employers too have a say in the initiation of new programmes and designing of the curriculum. This shall enable development of industry relevant programmes. Such type of 
collaboration will reduce the gap between what is taught and what is used in the real life scenario. Hands on training, in consultation or in collaboration with industry at the time of education will make learners' job ready and enable them to give productive output at their work places, there by contributing to the economic development of the country. Such type of alliance will also facilitate learners in providing learners a smooth transition from learning to earning.

Table 5. Areas for Collaboration

\begin{tabular}{clcc}
\hline $\begin{array}{c}\text { S. } \\
\text { No. }\end{array}$ & Areas of collaboration & $\begin{array}{c}\text { No. of } \\
\text { Responses }\end{array}$ & $\begin{array}{c}\text { Response } \\
\% *\end{array}$ \\
\hline 1 & $\begin{array}{l}\text { Providing employment to learners after course } \\
\text { completion }\end{array}$ & 57 & $77.0 \%$ \\
2 & Initiating a new programme & 55 & $74.3 \%$ \\
3 & Providing hands-on experience and training & 55 & $74.3 \%$ \\
4 & Framing the curriculum & 48 & $64.9 \%$ \\
5 & Providing internship and income & 47 & $63.5 \%$ \\
6 & Developing the delivery mechanism & 43 & $58.1 \%$ \\
7 & Designing the instruction & 42 & $56.8 \%$ \\
\hline
\end{tabular}

* Respondents may select more than one option, so percentages may add up to more than 100\%.

Recommendations from Employers for Improvement of Quality of ODL

Employers strongly feel that ODL has got immense potential to reach the masses across location, culture, perception, age, gender and time in a cost effective way. It is the answer to the challenges which convention higher education is facing today. It is therefore important to regularize and introduce reforms to preserve and revitalize ODL through policy interventions. Recommendations from employers stressed upon the quality of ODL education.

The quality can be regulated with the support of the government through (a) regulatory collaboration between various regulatory agencies like University Grant Commission (UGC), All India Council for Technical Education (AICTE) etc., to support and strengthen ODL (b) accreditation of ODL institutes to maintain quality and (c) recognition of degrees. Collaboration will bring together leaders in the field of Open and Distance Education for a comprehensive overview of this rapidly expanding system of Education, Training and Research \& Development.

With advancing globalization, accreditation and standards have become an integral part of Higher Education. For this purpose, there is a need to develop a system of accreditation for ODL institutes and programmes offered by them. It is important to deliberate on the strategy to identify broad parameters for quality assurance of various systems and subsystems of ODL for the purpose of accreditation. Accreditation can meaningfully bring quality in ODL and enable ODL system to address the challenge of recognition of degrees. It will be a great step towards bringing ODL at par with the mainstream Higher Education System and contribute to the national agenda. It will foster democratization of Higher Education due to which ODL was primarily conceived.

\section{CONCLUSION}

This research study has highlighted the major aspects to be looked upon for improving the skill development through ODL system. Employers, being an important stakeholder needs to be taken into consideration for introducing and implementation of reforms. In developing countries like India there is a stigma in the industry with the Technical and 
Vocational Education Training obtained through ODL. There is a need to change the mindset of the industry which is so used to age's old formal education system. However, this apprehension of the industry can be changed through

$>$ Policy intervention from the policy makers

$>$ Seeking the employers view in policy forming

$>$ Introducing industry relevant programmes

$>$ Involving the employers during curriculum planning and development. This will also help them to understand the ODL system.

$>$ Incorporating appropriate technologies

$>$ Incorporating hands-on and apprenticeship

$>$ Inbuilt quality control and quality assurance

It is suggested that government agencies should implement recognition, accreditation, and industry relevant curricula. Professional skills should be made an integral part of academic programmes to make the learners job ready. Both the quality of ODL programmes and its linking with skill development will enable ODL system to bridge the gap between demand and supply of skilled manpower. Employers were also positive about the use of technology for imparting skills.

Cooperation and collaboration are known for facilitating and implementing ideas in a meaningful way however it is one of the most challenging aspects in an organizational functioning. Policy intervention at government level is much needed call of the time for ODL system. While it is important for the system to work towards the quality of education, it is also important to rope in hands-on experience and training within the curriculum so that life skills required in the jobs can be developed. ODL institutions need to collaborate and use technology for the skill development of ODL graduates and raising their employability quotient.

\section{BIODATA and CONTACT ADDRESSES of AUTHORS}

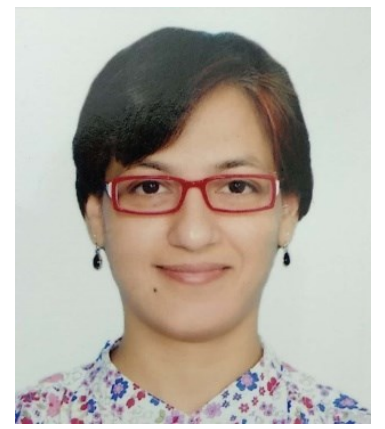

Dr. Anshu MIGLANI is working as Assistant Director (R\&D), Inter University Consortium for Technology-Enabled Flexible Education and Development (IUC-TEFED), IGNOU. She has come from multidisciplinary background which has endowed her with the knowledge of Basic as well as Applied Sciences . For the past 12 years, she has been a part of consultancy, capacity building (training \& education), research \& documentation coupled with industry experience. She has worked on a number of projects and provided consultancy on Natural Resource Management, Agriculture, Environment Impact Analysis etc., which utilize the knowledge of Geospatial technology. She has also been involved in various researches which has given me a number of publications. Her areas of interest are ICT applications in Education esp. mobile learning.

\section{Dr. Anshu MIGLANI}

Assistant Director (Research \& Development)

Inter University Consortium for

Technology-Enabled Flexible Education and Development (IUC-TEFED)

Indira Gandhi National Open University (IGNOU),

New Delhi-110068, India

Phone: +91-11-2957-2319

Email: anshu.miglani@ignou.ac.in 


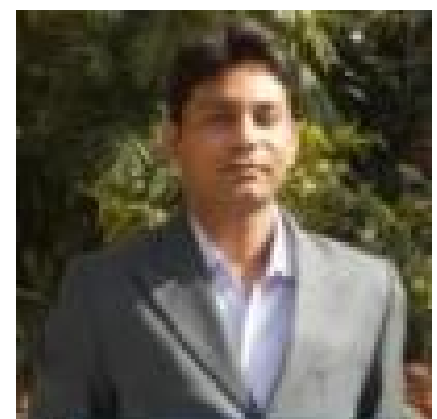

Ashish K. AWADHIYA has done M. Sc. (Life Science) from School of Life Sciences, Devi Ahilya University, Indore and UGC-CSIR NET. He has also done Post Graduate Diploma in Quality Management, MA in Distance Education (Gold Medalist). Currently he is working as Asst. Director (Training and Development), at Inter University Consortium for TechnologyEnabled Flexible Education and Development (IUC-TEFED), IGNOU. Mr. Awadhiya has eight year experience including corporate in the field of Training and Development and Quality Assurance. He has experience in field of Training and Development, Skill Development, Employee Training Management System. He is a trainer in the areas of e-learning, e-content development, Social Media Learning, Computer Added Learning. His are of interest include skill development, capacity building, e-learning, MOOCs, OERs, Open and Distance Learning etc. Currently he is looking after SWAYAM MOOCs and SWAYAM Prabha activities at IGNOU.

Ashish Kumar AWADHIYA

Assistant Director (Training and Development)

Inter University Consortium for

Technology-Enabled Flexible Education and Development (IUC-TEFED)

Indira Gandhi National Open University (IGNOU)

New Delhi-110068, India

Phone: +91-011-2957-2316

Email: akawadhiya@ignou.ac.in

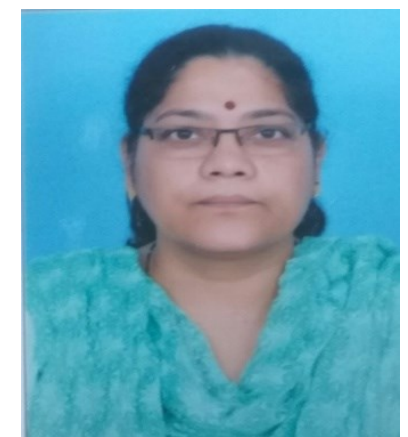

Dr Nisha SINGH, M.Sc.(Zoology), M.Ed., M.Phil., Ph.D.(Education), PGDEL (IGNOU), MIDT(OUM) is presently working as Deputy Director (R\&D), Inter University Consortium for TechnologyEnabled Flexible Education and Development. Dr Singh joined Indira Gandhi National Open University (IGNOU) in 2009 as a Programme Officer in DEP-SSA. Before joining IGNOU she was working as a Associate Professor in Faculty of Education and Allied Sciences, M J P Rohilkhand University, Bareilly, UP. She has long classroom teaching experience as Teacher Educator (1993-2009) in various Teacher Training Institutions (Department of Education, University of Delhi; Vasanta College for Women, Varanasi, UP; MJP Rohilkhand University, Bareilly, UP). She has experience in teaching B.Ed., M.Ed. classes. She has guided three Ph.D. students. She has published a book entitled 'Development of Monastic Education in India' and to her credit there are more than $\mathbf{2 0}$ articles and papers in various books and Journals. Her specializations are ICT Applications in Education and Education of Exceptional Children. E-Learning, OER, Open and Distance Edcation, Teacher Education are areas of her interest and deliberations in workshops and trainings. Presently she is looking after e-Gyankosh, SWAYAM and SWAYAMPRABHA activities at IGNOU.

\section{Dr. Nisha SINGH}

Deputy Director (Research and Development)

Inter University Consortium for

Technology-Enabled Flexible Education and Development (IUC-TEFED)

Indira Gandhi National Open University (IGNOU)

New Delhi-110068, India

Phone: +91-11-2957-2318

Email: drnisha@ignou.ac.in 


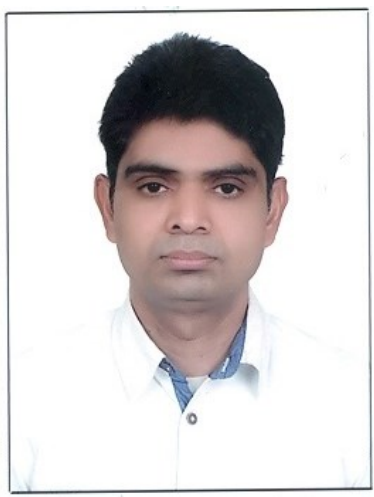

K. GOWTHAMAN is working as Deputy Director (T\&D), Inter University Consortium for Technology-Enabled Flexible Education and Development, IGNOU, Since November 2011. His academic interest areas are Training and Delevelopment on Online Educational System, Technology Enabled Support Services, elearning, e-Office and etc. He has also 17 years of industry experience in Software Application Development, Maintenance and Support activities. His specializations are Management Information System, Software Engineering, Multimedia Application Development, Improving Quality Process, Re-Engineering and Reverse Engineering. Currently he is looking after eGyankosh, SWYAM PRABHA and SWAYAM MOOCs activities at IGNOU.

Dr. K. GOWTHAMAN

Deputy Director (Training and Development)

Inter University Consortium for

Technology-Enabled Flexible Education and Development (IUC-TEFED)

Indira Gandhi National Open University (IGNOU)

New Delhi-110068, India

Phone: +91-11-2957-2317

Email: gowthaman@ignou.ac.in

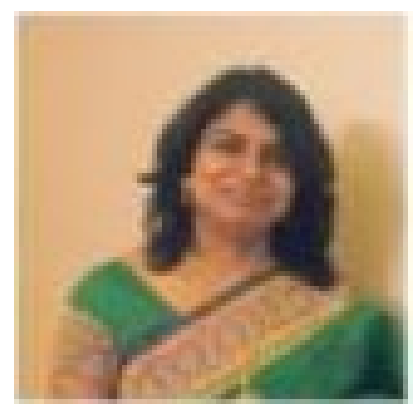

Dr. Gayatri KANSAL is Professor of Mechanical Engineering. She has done B. Tech in Mechanical Engineering and Doctorate from IIT Delhi in the field of automation. She has been Director IUC between November 2014 and August 2016. She also worked as the Chairperson of IGNOU Committee Against Sexual Harassment (I-CASH). She had been Director, School of Engineering and Technology, IGNOU. She is Program Coordinator of B. Tech in Mechanical Engineering and was coordinator B.Sc Nautical Science, she was instrumental in starting and designing of this programme which did not exist anywhere in India in its present form before. Based on this concept the first university for mariners i.e. Indian Maritime University has been developed in India. She has been working in the field of Open and Distance Learning since last 18 years and has vast experience in the field of Design and Development of the ODL programmes.

Dr. Gayatri KANSAL

School of Engineering and Technology (SOET)

Indira Gandhi National Open University (IGNOU)

New Delhi-110068, India

Phone: +91-11-2957-2921

Email: gayatrik@ignou.ac.in

\section{REFERENCES}

Aggarwal, S. (2016). Central pillar of employability: Skill development. Imperial Journal of Interdisciplinary Research, 2(3).

Awadhiya, A. K., Miglani, A., Gowthaman, K. (2014). ICT Usage by Distance Learners in India. Turkish Online Journal of Distance Education, 15(3), 242-253.

Awadhiya, A. K., Miglani, A. (2016). Mobile Learning: Challenges for Teachers of Indian Open Universities. Journal of Learning for Development-JL4D, 3(2), 35-46. 
Council of Graduate Schools and Educational Testing Service. (2012). Pathways through graduate school and into careers. Report from the Commission on Pathways Through Graduate School and into Careers. Princeton, NJ: Educational Testing Service. Retrieved

from http://www.pathwaysreport.org/rsc/pdf/19089_PathwaysRept_Links.pdf

FICCI, 2015. Skill Development in India 2015. http://www.kas.de/wf/doc/kas_428481522-2-30.pdf?151016072126

Gamage, D., Perera, I., \& Fernando, S. (2016). Improving effectiveness of MOOCs. AsiaPacific Society for Computers in Education All rights reserved. Asia-Pacific Society for Computers in Education. ISBN 9789868473584, 5.

Gauvreau, S. A., Hurst, D., Cleveland-Innes, M., \& Hawranik, P. (2016). Online professional skills workshops: Perspectives from distance education graduate students. The International Review of Research in Open and Distributed Learning, 17(5).

Government of India- Ministry of Human Resource Development https://swayam.gov.in/About. (accessed on 19 Jul 2017)

Government of India- Ministry of Skill Development \& Entrepreneurship. http://www.skilldevelopment.gov.in/nationalskillmission.html (accessed on 11 Feb 2017)

IGNOU, 2017. Three Decades of Distance Education. Planning \& Development Division, IGNOU, New Delhi, ISBN 978-93-86100-71-9, 70pp.

IGNOU, 2013. Social Credibility and Justice, MDE-411, Basic Issues of Open and Distance Education, New Delhi: STRIDE, IGNOU, 35.

IGNOU, (2001). Research Methods for Distance Education. ES-315 Research for Distance Education, New Delhi: STRIDE, IGNOU, 70-96.

Miglani, A., Awadhiya, A. K. (2017). Mobile learning: readiness and perceptions of teachers of Open Universities of Commonwealth Asia. Journal of Learning for Development-JL4D, 4(1), 58-71.

Mishra, A. K., \& Bartram, J. (2002). Skills development through distance education. Commonwealth of Learning, Vancouver.

Mnkandla, E., \& Minnaar, A. (2017). The Use of Social Media in E-Learning: A Metasynthesis. The International Review of Research in Open and Distributed Learning, August, 18(5), http://www.irrodl.org/index.php/irrodl/article/view/3014/4273 (accessed on 2nnd Jan 2018).

Mohapatra, B., \& Mahapatra, S. K. (2016). Gender, Skill Development and Employability: The Context of Open and Distance Learning Perspective in India.

Robles, M. M. (2012). Executive perceptions of the top 10 soft skills needed in today's workplace. Business Communication Quarterly, 75(4), 453-465.

Sharma, L. \& Nagendra, A. (2016). Skill Development in India: Challenges and Opportunities. Indian Journal of Science and Technology, Vol 9(48), 1-8. 